\title{
Application of Political Propaganda by Government in the Resolution of ASUU/FGN Industrial Conflict of 2013
}

\author{
Patrick Ukim Ineji, Veronica Bassey-Duke, Ndoma J. Brown \\ Department of Mass Communication, Faculty of Communication Technology, Cross River University of \\ Technology, Calabar, Nigeria \\ Email: ndomabrown@gmail.com
}

Received 6 June 2014; revised 10 July 2014; accepted 5 August 2014

Copyright (C) 2014 by authors and Scientific Research Publishing Inc.

This work is licensed under the Creative Commons Attribution International License (CC BY). http://creativecommons.org/licenses/by/4.0/

(c) (i) Open Access

\begin{abstract}
In Nigeria, the prerogative attached to political propaganda is often superfluous in resolving national disputes, culpable of inimically truncating or abducting privileges of citizenry. This approach lingered in the 2013 feud that existed between ASUU and FGN in not sustaining a corporate integrity. The researchers employed Conflict and Authoritarian Media Theories in unraveling different propaganda strategies masterminded by FGN. In the fate of recognizing education for self and technological exploits, parochialism should be moderated, when justifiable priorities are misappropriated. This paper frowned at the gluttonic feast on political propaganda in our purported scientific society; the likes of education should be treated with caution, valued as the bedrock of socio-technological advancement; absolute care with politicized acrimonies was frankly admonished.
\end{abstract}

\section{Keywords}

ASUU, Conflict, FGN, Propaganda, Stakeholders and Unionism

\section{Overview}

From whatever angle education is viewed, she remains the indefatigable pillar of advancement. Ipinyomi (2013) in African Examiner remonstrated this in "education is the only area we think Nigeria can advance her course in the community of nations". In this competitive world everyone who wants to play a significant part and be reckoned with must move with the world and the business world moving at a very faster pace. This is why we shall continue to advocate and campaign to the developing countries, especially Africans, to develop their edu- 
cational systems and capture all age groups. Africa's hope is in educating its workforce and citizens appropriately. This is the single factor that has shaped the future of Africans since independence must not be abandoned now. Objectively, the researchers believed that managing Nigeria's public universities has always left them undemocratic and insecure. These poor conditions of service of university staff, which serve as a disincentive to work, dilapidated and inadequate infrastructure in our universities, shortage of teaching aids, research laboratories, libraries, qualified and experienced lecturers and a less conducive learning environment occasioned by serious security concerns due to the increasing menace of cult activities as well as the anti-intellectual stance of the establishment led to mass exodus of generations of well trained, experienced and world class intellectuals such as Professors Chinua Achebe and Sam Okoye (of blessed memory), Wole Soyinka, Niyi Osundare, and Biodun Jeyifo and many others to Europe, North America, South Africa and Asia in search of the proverbial greener pastures leading to the brain-drain syndrome plaguing the Nigerian university system in contemporary history. The above problems and myriads of others have to some extent, tended to accelerate or decelerate the pace and dynamics of dysfunction in the growth and development of the public university system in Nigeria and the promotion of viable intellectual culture (Daily Times, 2013).

These ugly experiences led to 2013 ASUU/FGN industrial logjam, which resulted in a prolonged national strike by members of the Academic Staff Union of University (ASUU), generated a lot of concerns among stakeholders in the educational sector. In fact, there was unbridled anxiety, anger, uneasiness and frustration among university students, parents, clergies, traditional rulers, business men and women, civil society groups, civil servants and politicians who were enraged at what perceived as ASUU insensitivity towards the plights of students and parents despite Federal Government offer. Unfortunately, as Government remains relentless in brainwashing the minds of the public with highly orchestrated and opulent political propaganda and other form using public media. Most Nigerians never cared hoot to hear from the side of ASUU to get balanced, accurate and fair position of the issue. Noting that most people never bothered to know was that Government reneged on an agreement that it freely entered with the academic staff union in 2009 and equally repudiated the Memorandum of Understanding (MOU) of January 2012, which was initiated at the instance of Government. Maintaining its position and unwillingness to implement the provisions of the agreement, Government impressed it upon the public that some of the provisions in the agreement were not implementable whereas, Academic Staff Union of Universities (ASUU) maintained that Government should show integrity by implementing the 2009 agreement and the MOU of 2012 as the only way out of the impasse.

In inimical retrospect, employment relationship, the traditional purpose of industrial strike is for organized labour to continually inflict economic pain on recalcitrant employers till demands are pressed home and met. But the FGN-ASUU version of industrial actions poses reasons for skepticism. The employer no longer feels any pinch from strike action. Rather the poor man on the streets, recharge card sellers, commercial bus drivers, photographers, food sellers, and booksellers, who operate on and around campuses, are the ones receiving the resultant economic burden. Students suffer and teeth-garnish as a result of lingering industrial strikes and acrimony in the ivory towers. They are doomed to vagabondage and crime as they soon become effective tools in the hands of rapacious and nefarious political leaders who use them for perpetrating their political violence through rigging, thuggery or other vices. The Government that they fight is not anyway affected and we make noise in the media just for nothing (Saheed, 2012). For these and other obvious reasons we have warranted this study in examining the propaganda employed by Government and suggestive avenues of reconciling issues so that an equitable integrity is sustained between ASUU and FGN, in forestalling repetitious occurrences.

\section{Conceptual Clarifications}

\subsection{Understanding the Concept of Propaganda}

Propaganda is one of the most potent subversive communication tools and is often employed by Government during crisis periods.

Quatler, Terrace 1962 cited in Jowett and O’Dowell (2012: p. 2) defines propaganda "as the deliberate attempt by some individuals or groups to form, control or alter the attitudes of other groups by the use of instruments of communication with the intention that in any given situation, the reaction of those so-influenced will be that desired by the propagandist".

Jowett and O’Donnell (2012: p. 7) share a similar view when they define propaganda: 
As the deliberate systematic attempt to shape perception, manipulate cognition and direct behavior to achieve a responds that furthers the desired intent of the propagandist.

The basic ingredient in the above definition focuses on the communication process, which lies on the purpose of the process.

In the same view, Kamalipour (2007: p. 23), avers that:

"The term propaganda is not simple to define, nor is it always easy to identify—simply put, the purpose of propaganda is to persuade and covert by using intentionally selective and biased information”.

Nelson (1996: p. 20) says:

"Propaganda is neutrally defined as a systematic form of purposeful persuasion that attempts to influence the emotions, attitudes, opinions and actions of specified target audience for ideological, political or commercial purposes through the control transmission of one-sided messages (which may or may not be factual) via mass and direct media channels...”

Hasan (2010: p. 420) defined propaganda as a specified type of message presentation directly aimed at influencing the opinions or behavior of people, rather than impartially providing information.

In an attempt to reconcile a variety of definitions of propaganda, Wilson (2005: p. 84) maintains that:

The political activist sees any information from Government source as propaganda because he has learned to mistrust Government leaders. To the politician, propaganda is a legitimate tool which may be employed to advance the interest which he believes coincides with that of the ordinary people when this is not so.

From the foregoing it can be safely summed that proper understanding of propaganda depends on the context in which it is employed and applied; it utilizes the instrument of communication; it is biased; it appeals to emotions; it has a desperate intent to convert audiences.

Arising from the above therefore, it is possible to infer that there is difficulty in working out a formal definition of propaganda. Most students of the subject agree that propaganda has to do with any ideas and beliefs that are intentionally propagated. Although it is used in controversial situations, most experts agree that it is also used to promote ideas. Propaganda ranges from the selfish and the subversive to the honest and above board promotional efforts; it can be concealed or open; emotional or containing appeal to reason or combination of logical and emotional appeals.

\subsection{Political Propaganda Explained}

Our discourse on political propaganda dwells on issues, policies and general matters patterning to governance and exclusive of propaganda bordering on mainstream advertisement. In the context of this discourse, political propaganda refers essentially to communication activities employed by political actions with the intention to further the interest of the political office holders or Government in general; it is the means, by which political governance is sustained.

Political propaganda can be deployed to achieve devious means under certain situations and circumstances, Hasan (2010: pp. 421-422) lends credence to this view when he avers:

... Propaganda has an inherent emotional under current which can and is often used to create effect for negative purposes. It has the ability to: Awaken passion by confusing the issues; it made the important issues and facts seem trifling or unimportant; it keeps the channels of communication full of exciting stuff and it keeps people battling in the dark.

The above scenario played itself out during the four months ASUU strike of 2013. Political propaganda became dominant and Government officials used it to spread the campaigns of lies and intimidation in order to manipulate or brainwash the public. Unfortunately, Government propaganda could not resolve the crisis as early as expected by Government propaganda machinery because the desire was to attain selfish end to the detriment of University dons. This tactics was perceived by ASUU as unfair as it misled the public with the wrong signal that Union members were unpatriotic and insensitive to the plight of the suffering students, parents and the University system. 
Baran and Davis (2006: p. 73) echoes this view:

... Propaganda violates the most basic rules of fair democratic political communication. Propaganda freely uses lies and deception to persuade. If people could be taught to critically evaluate propaganda messages, they could learn to reject them as unfair and false.

There is no doubt that political propaganda has been of major significance in the past decades, so the Nigerian situation at the time is not strange. All Government of the world at one time or the other, employ it during crisis situation to survive or wriggle out of difficulty. Political leaders have since realized that the power b of propaganda is so latent and potent than the weapons of guns and canon. Lending credence to this view, SchulzeWechsugen (1934) cited in Baran and Davis (2006: p. 212) holds that "our leaders realized the power and the effect of this modern weapon which he described as a weapon without limits that thunders more loudly than canon fire that is more destructive than a gas attack".

Political leaders having realized the potency and necessity of their campaigns now use it to achieve their goals with impunity. In the view of politics, propaganda can cause the rise of political career and must be dependent upon at all times so that Political future can be guaranteed. It is seen as a powerful tool in molding the nature and thinking of the contemporary man. In order to achieve its desperate goal, Government realizes the need to organize and sustain a lasting moral force which must be firm, systematic and coherent to raise the morale of the nation and to control it based on sentimentality and "moral" feeling and understanding of the psyche of the masses. Politics depend on intuitive propaganda and the goals of the political leadership and its understanding of human psychology and perception of the people towards the goal desired.

\subsection{What Is Conflict?}

Conflict is an unavoidable phenomenon. As long as society exists with people harboring varying interests and striving to attain individual and collective goals, there is bound to be conflict. Hence, conflict is a necessary ingredient for the sustenance of society.

Therefore, from the foregoing, the society should not bother so much about conflict, but rather how conflict can be managed within.

In the course of striving for survival to attain individual and collective goals, human beings are bound to trample upon the interest of the other, and once one's goals crisscross or come into sharp contrast with another person, conflict is bound to arise. There are several types of conflicts, economic, political, cultural, religious etc.

The attainment of any of these goals can only be achieved through the management of conflict. It is the means, through which our social values, welfare, security, social change; personal and societal development can be actualized.

\subsection{What Then Is Conflict?}

In a society where there exist opportunities for competition and struggle for survival there is bound to be conflict. Citing Action Aid (1994) in Nwosu (2011) defined conflict "as a fight, a struggle, a disagreement between people with different ideas or beliefs; to be in opposition or disagreement over a matter or issue”. Oxford Dictionary, 1984, cited by Nwosu, who further categorized several definitions of conflict by different authors: to be in opposition or disagreement over a matter or issue. It can also be defined as perceived incompatibility of actions or goals (Mayer, 1993: p. 5) or as "the process that results when one person (or group of people) perceives that another person or group is frustrating or is about to frustrate an important concern” (Vechio, 1991: p. 40) or Greenberg and Barton, 1993, cited by Nwosu "as a process in which one party perceives that another party has taken some actions that will exert negative efforts on its major interest or is about to take such action”.

Conflict exist at different levels, individual or personal, group or organizational level. The theme of this paper is hinged on Union/industrial organizational conflict. This paper is concern with the way and manner Government applied instruments of communication at her disposal to sway public sympathy and portrayed the Union in negative light before the Nigerian publics.

Chambers 21st Century Dictionary, 2004, cited by Nwosu defines Conflict as disagreements; fierce argument; a quarrel; a clash between two different aims, interest, ideas etc. a struggle, fight or clash or battle usually on a lesser scale than a war, a clash between incompatible desires or needs sometimes leading to emotional turmoil. 


\section{Theoretical Framework}

\subsection{Conflict Theory}

This work is anchored on conflict theory as a basis for analysis. Conflict theory is premised on disorder, disagreement and open hostility among individuals and groups and lack of harmony in system parts. In the perspective of conflict theory, it is struggles over power and resources that are normal and harmonious cooperation that is unusual. Social structure is temporary and often fragile combination of competing social forces.

In conflict perspective, the task of the social scientist is to examine the sources of tension among people and groups with different amount of powers, techniques of conflict control and the ways in which the powerful maintain and enlarge their influence on all aspect of the social structure. In the conflict view, the social order at any particular moment is the outcome of struggles among groups of unequal power. The conflict perspective concern with who benefits from any given social arrangement? Conflict within the society is expressed through public protests, industrial conflicts (strikes and lockouts) as in 2013 FGN/ASUU industrial conflicts.

This theory is pertinent and relevant to this work in that it focuses on open disagreement between the Federal Government and the Academic Staff Union of Universities, ASUU based on unresolved issues contained in the terms of the 2009 FGN/ASUU agreement and the 2012 Memorandum of Understanding (MOU). Whereas ASUU maintained that the FGN had breached the terms of the agreement, the Federal Government saw nothing wrong repudiating some of the terms of agreement.

The relevance of this theory to this work is hinged on disharmony and disequilibrium created among the two factions and the suspension of academic programs in the Nigerian University system for over five months. We shall further explore the relevant application of this theory to study as we progress in the course of the paper. Another theory that is relevant and pertinent to this discourse is the Authoritarian press theory.

\subsection{The Authoritarian Media Theory}

This theory which was propounded in 1956 by Siebert Peterson and Schuman postulates that the media should do nothing that would undermine established authority or disturb order; the media should always be subordinate to established authority; the media should avoid offence to majority or dominant moral and political values; censorship should be justified to enforce these principles. Unacceptable attacks on authority, deviation from official policy or offences against moral codes should be criminal offences; journalist or other media professionals have no independence within their moral organization.

In the authoritarian media theory, whether the ownership was public or private, the system existed to serve the interest of Government in power. Under this system, Government exercise control over the media in various ways. In Nigeria, during the 2013 ASUU/FGN industrial conflict, Government used cruel and uncivilized methods to ensure that pro-ASUU protests in the country were suppressed and all such pro-ASUU protested were blacklisted from media coverage, especially Government owned media. In some cases, security personnel were drafted the scheduled venues where ASUU member were to publicized their grievances to allow the Nigerian public understand why her members were on strike.

This theory is relevant to this discourse in that Government exercised control and curtailed ASUU activities that were designed to express their views to the public, there was not only restriction to members by the use of instrumentality of the State but freedom of speech and expression by ASUU members was highly curtailed.

\section{Application of Political Propaganda in 2013 FGN/ASUU Conflict}

Propaganda is a strategic weapon of war employed by warring factions in crisis/conflict situations and each party strives to make the best use of it to achieve the desired result, the ultimate of which is to influence public opinion and sway public sympathy. At the height of the labour crisis, Government employed a plethora of deliberate falsehood, suppression of negative information that would likely implicate ASUU and lose standing with the public while promoting positive information, deliberate misinformation and distortion of facts all with the ultimate goal of swaying public sympathy. In realization that information is power, Government ensured that everything possible was done to win the sympathy and support the public in the desired direction.

The following specific political propaganda strategies were employed by the Federal Government of Nigeria to achieve her purpose. Also employed were all forms of propaganda, white propaganda, black propaganda and gray propaganda. 


\subsection{White Propaganda}

In this form of propaganda, the source of the propaganda is clearly identified and the information in the message tends to be accurate. This form of propaganda was employed when Government wanted to impress it on the public that it was genuinely concern with the plight of parents and the students who felt the prolonged strike.

In order to assuage and placate the grieving segments of the population, for instance, the Senior Special Adviser to the President on Public Communication displayed photo specimen of a letter from the Central Bank of Nigeria indicating the payment of 200 billion naira into a special account with the CBN. The essence was to portray the leadership of ASUU as unpatriotic and insensitive to the plights of stakeholders arising from prolong strike while portraying the Federal Government as patriotic and genuinely concerned.

\subsection{Black Propaganda}

Black propaganda occurs when the source is concealed or credited to a false authority and spread lies, persuasions and deceptions. It also includes all sorts of creative deceits. This was employed by Government when a group of women were hired under the aegis of Nigerian Market Women Association to protest in Abuja against ASUU members threatening to chase them out of their offices if they did not call off the strike within one week. It was clear that the hand of Government was behind the association.

Similarly, a group of students under the aegis of National Association of Nigerian Students demonstrated in Abuja and Lagos criticizing the ASUU for being insensitive to the plight of students and parents in spite of Government gesture. It was later realized that the arrowheads of the protests were not students in any university in Nigeria or abroad.

There was a mixed grill of lies and truths when at the height of the crisis, Government denied handing down a one-week ultimatum to the Vice-Chancellors of Federal Universities to compel lecturers to resume work failure of which will lead to their sack. The presidency later denied that the ultimatum was not from the presidency but from the Governing Council of Public Universities in the country. It was obvious that Government and Councils of Universities are not mutually exclusive as council members are appointees of the visitors of universities. Government simply decided to retrace its steps following bitter criticism of listing out such a dictatorial order to academics in a civilized and democratic society.

\subsection{Gray Propaganda}

Gray propaganda is somewhat between white and black propaganda. The source may or may not be correctly identified and the accuracy of the message or information is uncertain. At the height of the industrial conflict, the Senate President intervention was fraught with a deluge and disinformation and confusion when he asserted that those who signed the 2009 FGN/ASUU agreement were ignorant and did not know their left from their right. He also averred that it was impracticable for Government to pay such a huge sum of money amounting to over 800 billion naira in five years based on the 2009 FGN/ASUU agreement.

Again, it was mind bugging when a Senator and Education Committee member of Senate changed that it was preposterous for ASUU to demand for supervisory allowance when it was their statutory responsibility to do so.

The lies were very glaring when Government signed an agreement, which it refused to implement, but rather asked for re-negotiation and even discarded the $2012 \mathrm{MOU}$, which was at the instance of the FGN. Therefore, the request of the Government and the 2012 MOU was clearly deceitful. Yet the President who midwife the 2009 agreement as then the Vice-President during the Yar'Adua's Presidency feigned ignorance of the terms of agreement.

\subsection{Flag Waving}

The Federal Government of Nigeria appealed to the sensibilities of Nigerians by dangling the patriotic flag before the Nigerian public to give the impression that it was a patriotic duty for the academic staff to go back to classes whether or not their demands were met. This formed the basis of several appeals by concerned Nigerians to ASUU to call off the strike for the interest of our students who were languishing at home.

\subsection{Card Stacking}

The Federal Government employed this technique during the crisis when it dwelled on the payment of 130 bil- 
lion naira into public Universities in Nigeria but ignored the fact that it failed to implement other provisions in the agreement, including the payment of $\$ 200$ trillion naira yearly commencing from 2009 , it equally reneged on the MOU of 2012 which was at the behest of the Federal Government.

\subsection{Hasty Generalization}

Government have often impressed on the public that lecturers in Nigerian Universities were self-seeking and only interested in their personal welfare by demanding for a rise in their personal emolument. It has often been on the basis of this that Government was reluctant to accede to ASUU demands whenever the need arose.

\subsection{Red Herring}

This is presenting data or issues that, while compelling are irrelevant to the argument at hand, and then claiming that it validates the argument.

Government resorted to this device when it argued that provided substantial amount of the money for infrastructural development of public Universities, citing TET fund as one of the key achievements of the Government in this direction.

\subsection{Managing the News}

Government could only defend and maintain the stance that it has released 130 million to the Universities as arrears for earned allowances and kept assuring the public that the issues in dispute would soon be resolved with ASUU. The strike lasted for more than five months.

\subsection{Timing}

This was one of the greatest asset that Government deployed as a strategic device to manage or resolve the conflict. At certain strategic moment, Government made public speeches to placate it and assuaged the frustrated University students. This was designed to win public sympathy.

\section{Conclusion}

The political machination, contrivance and subterfuge, employed by Federal Government of Nigeria were opulent and orchestrated to serve as a strategic political goal. In a desperate effort to brainwash the public on all sorts of known and unknown political propaganda strategies were employed to attract public sympathy. There were more or less uncivilized and uncouth methods which include, hiring crowds under the guise of different associations to protest against the prolong strike by ASUU members. Some of the arranged (hired) protests were under the aegis of Nigerian Market Women Association while protesting in Abuja threatened to chase out lecturers from the campuses if the strike was not called off within a specific time frame.

Other cruel, uncivilized and undemocratic devices employed by the Government included among others using the police to lock up and barricade the gates of University campuses to prevent ASUU members from engaging in street protest to register and make their grievances known to the Nigerian public.

\section{Selected Opinions on the Way Forward}

In the most honest opinion of Ipinyomi (cited), the "strike was not only in terms of neither billion of naira nor that academic staff being just short change in emoluments and conditions of service alone. The whole national focus and approach to the education industry has been wrong from the military regimes. We henceforth expect experts and persons who are brave and ready to sacrifice to the education system as Chancellors and Vice Chancellors rather than traditional rulers and parochial individuals”. People who are insensitive to such dispute created a bastardized academic calendar for Nigerian public universities. This distasteful act was further crystallized by Rapoport (1974) as asymmetric and structure-oriented conflict due to its longstanding antagonistic and fractious nature which makes its resolution intractable and complicated, calls for constructive engagement on the side of both ASUU and FGN and deep reflection of ideological pragmatism rather than rigidity. The ASUU's leadership should as a matter of patriotism and strategic national interest sort for other ways of resolving industrial actions (Daily Times, 2013). 
In line with economy balance, it becomes imperative for Nigerian labour leaders, industrial relations experts and especially ASUU to fasten their belt and immediately embark on rigorous research to faction out alternative, or a corollary, to strike actions that will spare masses from being at the receiving end of the harsh outcomes of strikes. They should study the characteristics of modern day Government in Nigeria and craft out or device a new instrument of economic coercion capable of bringing modern day Nigerian Government to her kneel without giving the masses undeserved socio-economic torture. And even if alternative and workable solution is designed and developed, will Nigerian Government and the elite class provide environment or avenue for its successful adoption and implementation? All hope is not lost (Saheed, 2012).

Suggestively, the Government through the ministries of education, labour and productivity and their parastatals such as the NUC should always be alive to their responsibilities in ensuring that agreements are properly harmonized and implemented. They should also ensure that subsequent conditions are not over looked. ASUU and the ministries and other arms of Government also the Executive, the Legislature and the Judiciary should not allow the Nigeria project to fail. There should be an Education Think Tank who would always look at issues before it boils over. Membership of this body should be made up of people from all relevant ministries, Nigeria Labour Congress and ASUU. Government should not shy away from its responsibilities. The Government should dust all previous agreements with ASUU and ensure that they are carried out to the letter. Where there are encumbrances the issues should be made public. In line with UNESCO's declaration, Government should progressively increase education budget annually to 26 percent. ASUU strikes in this 21 st century should not be indefinite anymore. Recurring strikes in the university does the university system no good. What the public universities need now is a complete rescue (Aidelunuoghene, 2014). It is in that light that it is advisable to adopt a routine check on consultation, communication with and involvement of union in decision-making through representation, regular meetings and feedback sessions between FGN and ASUU. And in return for higher pay and better working conditions, unions should agree not to undertake industrial action for a certain period of time.

The "onus pro-ban-di" in this research which is no nation can progress without education. Education according to Nelson Mandela is the most powerful weapon that one can use to change the world. In that regard, stakeholders and concerned organizations should always be available to douse such unforeseen de-humanity, not adopt strategies that will present warring factions as being impenetrable but rather deposit affable and malleable attitude to protect and uphold progressive integrity for our public varsities' education.

\section{References}

Aidelunuoghene, O. S. (2014). ASUU Industrial Actions: Between ASUU and Government Is It an Issue of Rightness? Journal of Education and Practice, 5, 7-17. http://www.iiste.org/Journals/index.php/JEP/article/download/11201/11692

Baran, S. J., \& Davis, D. R. (2006). Mass Communication Theory: Foundations, Ferment and Future (4th ed.). Belmont: Thomson Wadsworth.

Daily Times (2013). http://www.dailytimes.com.ng/opinion/fgn-asuu-crisis-need-or-ideological-pragmatism

Hasan, S. (2010). Mass Communication: Principles and Concepts. New Delhi: CBS Publishers Distributors PVT Ltd.

Ipinyomi, R. A. (2013). African Examiner.

http://www.africanexaminer.com/eventually-asuufgn-faceoff-would-end-but-for-wrong-reasons/

Jowett, G. S., \& O’Donnell, V. (2012). Propaganda and Persuasion (5th ed.). London: Sage.

Kamalipour, Y. R. (2007). Global Communication (2nd ed.). Belmont: Thomson Wadsworth.

Mayer, D. (1993). Social Psychology. New York: McGraw Hill, Inc.

Nelson, R. A. (1966). A Chronology and Glossary of Propaganda in the United States. USA: Greenwood Press.

Nwosu, I. E. (2011). Conflict Management Communication and Mass Media: A Conceptual Theoretical and Introductory Analysis. In I. E. Nwosu, \& D. Wilson (Eds.), Communication Media and Conflict Management in Nigeria (pp. 1-21). Enugu: Prime Targets Ltd.

Quatler, T. A. (1962). Propaganda and Psychological Welfare. New York: Random House.

Saheed, O. K. (2012). http://klatz238.blogspot.com/

Vechio, R. (1991). Organizational Behaviour. Orlando: Dryden Press.

Wilson, D. (2005). New Perspectives in Communication. Ibadan: Stirling-Hordon Publishers (Nig.) Ltd. 
Scientific Research Publishing (SCIRP) is one of the largest Open Access journal publishers. It is currently publishing more than 200 open access, online, peer-reviewed journals covering a wide range of academic disciplines. SCIRP serves the worldwide academic communities and contributes to the progress and application of science with its publication.

Other selected journals from SCIRP are listed as below. Submit your manuscript to us via either submit@scirp.org or Online Submission Portal.
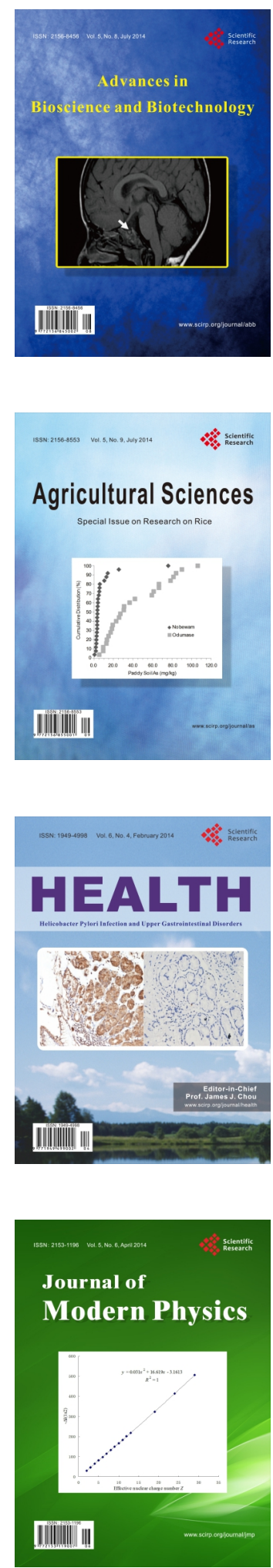
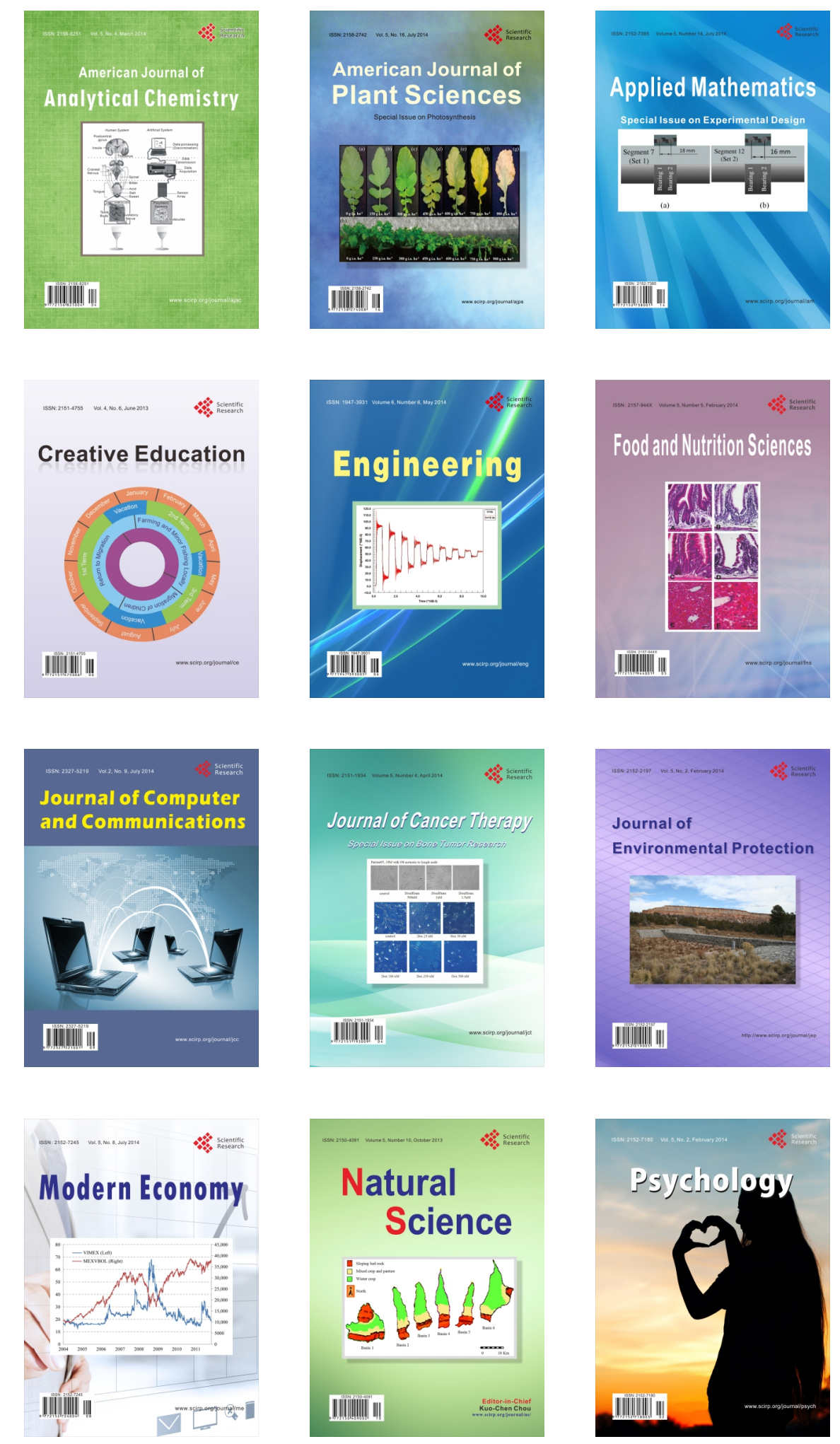